\title{
Invasion success of a widespread invasive predator may be explained by a high predatory efficacy but may be influenced by pathogen infection
}

\author{
William N. W. Fincham (1) Alison M. Dunn (1) - Lee E. Brown (1) \\ Helen Hesketh (1) - Helen E. Roy (1)
}

Received: 12 December 2018/Accepted: 30 July 2019/Published online: 27 August 2019

(C) The Author(s) 2019

\begin{abstract}
Invasive alien species (IAS) can drive community change through ecological interactions. Parasites and pathogens can play an important role in community function including mitigating or enhancing IAS impacts. Despite this, the degree to which pathogen pressure influences IAS impacts remains poorly understood. We quantified the predatory behaviour of the highly invasive alien harlequin ladybird (Harmonia axyridis) and two UK native species, the 7-spot (Coccinella septempunctata) and 2-spot (Adalia bipunctata) ladybirds, using comparative functional response experiments. We investigated the impacts of pathogen infection on the predatory ability of the ladybirds by exposing individuals to Beauveria bassiana, a widespread entomopathogen. Invasive $H$. axyridis was a more efficient predator than
\end{abstract}

Electronic supplementary material The online version of this article (https://doi.org/10.1007/s10530-019-02067-w) contains supplementary material, which is available to authorized users.

W. N. W. Fincham · A. M. Dunn $(\bowtie)$

Faculty of Biological Sciences and water@leeds,

University of Leeds, Leeds, UK

e-mail: a.dunn@leeds.ac.uk

L. E. Brown

School of Geography and water@leeds, University of

Leeds, Leeds, UK

H. Hesketh · H. E. Roy

Centre for Ecology \& Hydrology, Wallingford, UK both the native $A$. bipunctata and $C$. septempunctata, often having higher attack and/or lower prey handling time coefficients, whereas native A. bipunctata were the least efficient predators. These differences were found in both adult and larval life-stages. Beauveria bassiana infection significantly altered the predatory efficiency of adult and larval ladybird predators. The effects of pathogenic infection differed between species and life-stage but in many cases infection resulted in a reduced predatory ability. We suggest that the interactions between IAS and pathogens are integral to determining invasion success and impact.

Keywords Beauveria bassiana $\cdot$ Functional response · Harmonia axyridis - Invasive alien species . Parasite $\cdot$ Predator

\section{Introduction}

The rate of species invasions has increased in recent decades with the expansion of global trade and movement, and further rate increases appear likely (Levine and D'Antonio 2003; Hulme 2009; Seebens et al. 2017; Pfliegler et al. 2018). As a result, understanding the impacts of species invasion events has rarely been more important. The impacts that IAS can impose on native systems vary with respect to their trophic position and key functional behaviours, such 
as predation, which can also facilitate invader success (Salo et al. 2007; Bellard et al. 2016). Although characteristics of the invader can influence its effects, they can also differ according to characteristics of the recipient community. Parasites and pathogens play key roles within communities and can provide resistance to species invasions and modify the impacts of invading species, in addition to colonising novel areas as IAS themselves (Hatcher et al. 2014; Vilcinskas 2015; Roy et al. 2016b). Key functional roles are undertaken by parasites and pathogens through lethal and sub-lethal trait effects (Dunn and Hatcher 2015). Lethal effects of parasites can affect host population densities and result in population declines whereas the sub-lethal effects of infection can result in more complex impacts (Hatcher et al. 2014; Dunn and Hatcher 2015). For example, Roy et al. (2008b) provided evidence that harlequin ladybirds (Harmonia axyridis; Coleoptera, Coccinellidae) infected with Beauveria bassiana (Ascomycota, Cordycipitaceae) showed reduced egg production. Sub-lethal effects of parasites can also affect species with which hosts interact; for example, Dick et al. (2010) showed that Gammarus pulex (Crustacea, Amphipoda) infected with Echinorhynchus truttae acanthocephalan worms consume prey at an increased rate compared to uninfected conspecifics whereas Iltis et al. (2018) show similar results for infected Dikerogammarus villosus (Crustacea, Amphipoda). Despite their widespread presence within communities, parasites and pathogens are often absent from studies investigating the impacts of IAS (Hatcher et al. 2012), potentially resulting in oversimplified study systems that are unlikely to be representative of those in the field. However, it should be noted that efforts are ongoing to account for such interactions within some study systems (for example, with respect to $H$. axyridis see Haelewaters et al. 2017). Accounting for these effects not only provides insight as to species behaviours at suboptimal health, but also the role of parasites and pathogens during species invasions. Ultimately, understanding how species interact with parasites and pathogens is essential to accurately predict the ecological impacts of current and future invasive alien species.

Predation can be a key way in which IAS can influence native communities (e.g., Doherty et al. 2016). Predatory behaviour can be quantified through the use of predatory functional responses which describe the relationship between a species' resource use and the availability of that resource (Holling 1959). Functional response studies aim to replicate one part of a complex interaction between predators and their prey in a simplistic form, specifically, how a predator's rate of prey consumption changes with respect to prey density. Functional response experiments have been shown to correctly predict the impact of multiple invasive alien species, for example the 'bloody red' shrimp (Hemimysis anomala) (Dick et al. 2013). Functional response experiments provide a percapita measure of predatory ability and subsequently predatory pressure imposed on the prey species which can be compared between species and/or treatments and used to estimate population level impacts (Dick et al. 2017b; Laverty et al. 2017). Predatory functional responses have historically been used in population and community ecology as well as in pest management via biological control (for example O'Neill 1990; Sabelis 1992; Cuthbert et al. 2018). More recently, predatory functional responses have been applied within invasion ecology to understand and predict the impacts of invasive species (Alexander et al. 2014; Dick et al. 2017a; Uiterwaal and Delong 2018). Functional response experiments enable predation behaviour to be defined as one of three response types (I, II and III) and predatory coefficients to be calculated [handling time $(h)$ and attack rate $(a)$ ] (Holling 1959) across a range of prey densities. The functional response type can inform the likely ecological impact of the predator on the prey population. For example, a predator displaying a type II relationship could be expected to have a destabilising impact on the prey community as prey would be reduced to low densities or result in localised extinction (Hassell 1978). Conversely, a type III relationship suggests that the predator is likely show prey switching behaviour when the primary prey species reaches low densities, suggesting a more stable relationship with the prey community (Murdoch and Oaten 1975). Ladybird assemblages within the UK provide a model system for studying the impacts of an IAS within a community context (Roy et al. 2016a).

The harlequin ladybird ( $H$. axyridis) is a highly invasive coccinellid predator that has invaded throughout the world aided by multiple releases as a biological control agent (Roy et al. 2016a; Camachocervantes and Ortega-iturriaga 2017). Harmonia axyridis will predate the immature stages of the 
monarch butterfly (Danaus plexippus) (Koch et al. 2003). In addition to impacting prey species, $H$. axyridis has also led to declines of native ladybird populations through, at least in part, intra-guild predation (Ware and Majerus 2008; Katsanis et al. 2013). Harmonia axyridis now dominates many Coccinellidae assemblages throughout its invaded range (e.g. Brown and Roy 2017) which has resulted in reduced species diversity (Harmon et al. 2007; Koch and Galvan 2008; Bahlai et al. 2014; Grez et al. 2016). Following the arrival of $H$. axyridis in the UK in 2004, the 2-spot ladybird (Adalia bipunctata) showed a decline of $44 \%$ while 7-spot ladybird (Coccinella septempunctata) populations showed no significant change (Roy et al. 2012). Both of these species are historically common in the UK. The predatory ability of $H$. axyridis is believed to have been instrumental in the population declines of native Coccinellidae whilst giving the invasive species a competitive advantage, therefore facilitating its continued spread (for example Majerus et al. 2006; Xue et al. 2009; Abbott et al. 2014; Wu et al. 2018). Harmonia axyridis has been described as a voracious aphid predator (Majerus et al. 2006), however, the impacts on prey populations within the invaded range are less studied (Roy and Brown 2015; Roy et al. 2016a).

Beauveria bassiana is a widespread entomopathogenic fungus, found in multiple habitats including soils (Ormond et al. 2010), hedgerows (Meyling and Eilenberg 2006), and trees (Ormond et al. 2010; Howe et al. 2016), and is known to interact with UK Coccinellidae. Ormond et al. (2006) show that $B$. bassiana is a major cause of overwintering mortality for native $C$. septempunctata. While there have been no published field records of $B$. bassiana infection in A. bipunctata, Roy et al. (2008b) suggest this could be due to differences in habitat use, which result in A. bipunctata encountering B. bassiana less frequently. Roy et al. (2008b) also provide evidence, through a laboratory study, that A. bipunctata are similarly susceptible to $B$. bassiana infection as $C$. septempunctata, with both native species being more susceptible to pathogenic infection than $H$. axyridis. Howe et al. (2016) also report instances of infection in invasive alien $H$. axyridis field populations. Infection at lower doses can also be long lasting and result in sub-lethal trait mediated effects; for example, Roy et al. (2008b) showed that B. bassiana infection reduces egg production of $H$. axyridis. Despite the recorded instances of infection, $H$. axyridis is known to be less susceptible to $B$. bassiana than many native ladybird species (Cottrell and Shapiro-Ilan 2003; Roy et al. 2008b; Verheggen et al. 2017; Haelewaters et al. 2018) and this is likely due to $H$. axyridis' advanced chemical defences (Koyama and Majerus 2007; Roy et al. 2008a; Shapiro-Ilan and Cottrell 2011; Verheggen et al. 2017; Gegner et al. 2018). Despite $H$. axyridis commonly interacting with $B$. bassiana, our understanding as to how $B$. bassiana infection changes $H$. axyridis behaviour in relation to those natives which have coevolved with this pathogen remains incomplete. For example, should $B$. bassiana infection reduce the ability $H$. axyridis to forage efficiently this could result in reduced pressure on aphids through predation and on native ladybird communities through competition and intra-guild predation.

In this study we aimed to compare the predatory behaviour of the invasive alien $H$. axyridis, and two UK native ladybird species; $A$. bipunctata and $C$. septempunctata, during their larval and adult life stages, so as to better understand the ecological impact of the $H$. axyridis invasion and any potential insights as to $H$. axyridis' invasion success. So as to correctly define predatory functional responses, a process that is often challenging, we used three statistical techniques; linear regression, LOESS curve fitting, and AICc scores. We compared adult and larval $H$. axyridis with adult and larval A. bipunctata and adult $C$. septempunctata. We also investigated how pathogen infection impacts the predatory ability of the three species across their larval and adult life stages by exposing individuals to a sub-lethal dose of $B$. bassiana. While recorded instances of $B$. bassiana infection in $H$. axyridis and $A$. bipunctata are rarely observed in the field, such infections are known to occur and could feasibly change in the future, potentially as a result of spillover from the invasive H. axyridis. Additionally, any changes in the susceptibility of either $H$. axyridis or $A$. bipunctata to $B$. bassiana would likely increase the exposure of the other co-occurring ladybird species to B. bassiana. We hypothesised that: the invasive alien $H$. axyridis would demonstrate more efficient predatory behaviour than the native species. Efficient predatory behaviour was defined as having a higher overall functional response relationship, increased attack rate or reduced handling time. We 
further investigated how sub-lethal $B$. bassiana pathogenic infection would impact the predatory efficiency of the three ladybird species as this could shed light on the ecological impacts of $H$. axyridis and how these could change when exposed to a widespread pathogen.

\section{Materials and methods}

\section{Insect cultures}

We collected first and second larval instars of $H$. axyridis and adult $C$. septempunctata in Oxfordshire $\left(51^{\circ} 60^{\prime} \mathrm{N} ;-1^{\circ} 11^{\prime} \mathrm{W}\right)$ in summer (June-August) 2016 through visual and sweep net sampling of vegetation. Due to their scarcity, we purchased A. bipunctata first and second instar larvae from an industrial supplier (Green Gardener, UK) and, as they were also scarce in this particular field season, we only collected adult $C$. septempunctata. Therefore, no larval trials were conducted with $C$. septempunctata larvae. All individuals were maintained at constant conditions $\left(20{ }^{\circ} \mathrm{C}, 16: 8 \mathrm{~L}: \mathrm{D}\right.$ cycle) for at least 7 days prior to experimentation. We reared $H$. axyridis and $A$. bipunctata larvae in control conditions until their use in either larval or adult experiments. We fed individuals a mixed diet of sycamore aphids (Drepanosiphum platanoidis; frozen, mixed age classes), Ephestia kuehniella (Lepidoptera, Pyralidae) eggs (Entofood, Koppert, the Netherlands) and an artificial diet (detailed by Roy et al. 2013). We purchased English grain aphids (Sitobion avenae) from a commercial supplier (Ervibank, Koppert, the Netherlands) and reared them in the same conditions on the wheat plants on which they were received. We sexed adult ladybirds using established physical characteristics (McCornack et al. 1980; Roy et al. 2011). We used females in experimental trials as they are known to consume prey at higher rates than males (Xue et al. 2009; Gupta et al. 2012; Honek et al. 2017). Due to the inability to sex ladybird larvae, the larval treatments were of mixed sex. All larval treatments used fourth instar ladybird larvae.

\section{Beauveria bassiana infection}

We cultured B. bassiana from a commercially available product (Botanigard WP, strain GHA) on
Sabouraud dextrose agar (SDA) in Petri dishes in darkness at $25^{\circ} \mathrm{C}$. We prepared single spore isolations from these cultures, and subsequently sub-cultured under the same conditions before being stored at $-20{ }^{\circ} \mathrm{C}$ in $10 \%$ glycerol (v/v sterile milli-Q water) as a cryoprotectant. Thawed sub-cultures were macerated, spread onto fresh SDA plates and cultured for approximately 14 days until sporulation. We prepared spore suspensions in $0.03 \%$ Tween $20(\mathrm{v} / \mathrm{v}$ in sterile water) surfactant to reduce spores clumping together and the concentration of the resulting suspension was estimated using a Neubauer improved haemocytometer. We produced a $10^{6}$ spores $\mathrm{ml}^{-1}$ dilution from the stock suspension approximately $16 \mathrm{~h}$ prior to the experiment, stored on-ice and homogenised before use in experiments. This dose was aimed to provide an ecologically relevant dose that could feasibly impact predatory behaviour (Roy et al. 2008b).

We inoculated ladybird predators with one of two treatment solutions; a control treatment of $0.03 \%$ Tween 20 or a $10^{6}$ spores $\mathrm{ml}^{-1}$ B. bassiana spore suspension for infection treatments. Roy et al. (2008b) report the $\mathrm{LD}_{50}$ (median lethal dose) of native $C$. septempunctata and A. bipunctata were similar at $10^{6}$ and $10^{6.2}$ spores $\mathrm{ml}^{-1}$ respectively whereas invasive alien $H$. axyridis had an $\mathrm{LD}_{50}$ of $10^{9.6}$ spores $\mathrm{ml}^{-1}$. Individuals were inoculated by inversion (five times) in $1 \mathrm{ml}$ of inoculum and were placed on filter paper (Whatman No. 1) in a Büchner funnel to remove excess inoculum. All equipment was cleaned with 95\% ethanol between treatments. Following exposure to $B$. bassiana, treatment groups were housed separately to prevent contamination and starved for $8 \mathrm{~h}$ to standardise gut contents before the start of the experiment.

\section{Experimental methods}

Experimental arenas consisted of a Petri dish $(90 \mathrm{~mm})$ and contained blades of winter wheat (Triticum aestivum; ten strips, $40 \mathrm{~mm}$ in length) embedded in $2 \%$ water agar, approximately four $\mathrm{mm}$ in depth, so as to increase habitat heterogeneity. Filter papers (Whatman No. 1) were positioned in the lids to moderate moisture levels. Wheat was grown from seed (Syngenta) for 14 days before use. Grain aphids (Sitobion avenae) were provided as a prey resource at known densities of live second and third instar individuals. 
Fourth instar larval treatments were provided with prey densities of; 1, 2, 4, 8, 16, 32, 64 and 128 individuals. Adult treatments received prey densities of 1, 2, 4, 8, 16, 32, 64, 128 and 256 individuals. Adults received an additional prey density treatment as they are known to consume more prey then larvae. We aimed to replicate each treatment combination five times, due to ladybird mortality the total number of treatment replicates varied between four and six (Supplementary Table 1). Each prey density was replicated five times with a control treatment, consisting of the same experimental areas and prey densities as the adult and larval treatments with no predator present.

Predators were weighed after their starvation period before being added to the experimental arenas. The experiment ran for $24 \mathrm{~h}$ at constant conditions during which time predation of aphid prey could occur. After $24 \mathrm{~h}$ the ladybirds were removed from the arenas and remaining prey were counted. No cases of partial consumption were observed. Individuals were starved for a further $12 \mathrm{~h}$ before resuming a mixed diet and were monitored for mortality over the next 14 days. Adult cadavers, collected within the 14 day postexperiment observation period, were surface sterilised using a $1 \%$ bleach solution to reduce contamination, before being plated out on $2 \%$ water agar and incubated in darkness at $25^{\circ} \mathrm{C}$. Incubated cadavers were visually checked for signs of fungal sporulation for a period of 14 days.

\section{Statistical analysis}

All statistical analyses were undertaken in $\mathrm{R}$ version 3.3.2 and RStudio version 1.0.136 (R Core Team 2016; RStudio 2016). We compared ladybird masses with respect to species and treatment using ANOVA and TukeyHSD post-hoc statistical tests for both life stages. The number of prey surviving in predator treatments was compared to the control treatments using linear regression with, in response to signs of overdispersion, a quasipoisson error structure. We compared the number of prey consumed in the predator treatments between species and treatments, for both larvae and adult predators, using generalised linear models with quasipoisson error structures.

\section{Functional responses}

Functional response curve fitting was undertaken in $\mathrm{R}$ using the bbmle and emdbook statistical packages (Bolker and R Development Core Team 2014; Bolker 2016). Defining predatory functional response relationships can be difficult. In an attempt to overcome this, we used three methods to characterise predatory behaviour; linear regression of the proportion of prey eaten against prey density, second order Akaike information criterion (AICc) values and the qualitative inspection of non-parametric locally weighted scatter plot smoothing (LOESS) curves (Juliano 2001).

Functional response relationships were fitted using Holling's original type I equation (Eq. 1), Rogers' type II equation (Eq. 2), and Hassell's type III equation (Eq. 3). Hassell's type III and Rogers' type II equations are similar however, while Rogers' type II includes an attack rate parameter (a), Hassell's type III assumes the attack rate varies with prey density via a hyperbolic relationship. Rogers' type II and Hassell's type III equations both account for prey depletion (Rogers 1972; Hassell 1978) and rely on the Lambert $W$ function (Bolker 2016).

$N_{e}=a T N_{0}$

$N_{e}=N_{0}\left(1-e^{\left(a\left(N_{e} h-T\right)\right)}\right)$

$N_{e}=N_{0}\left(1-e^{\frac{\left(d+b N_{0}\left(h N_{e}-T\right)\right)}{1+c N_{0}}}\right)$

In all equations $N_{e}$ denotes prey consumed, $N_{0}$ is the number of prey provided, $T$ is the time during which behaviours occurred, $a$ and $h$ are attack rate and handling time coefficients of the predators. In Hassell's type III equation (Eq. 3) $b, c$ and $d$ are used to calculate the hyperbolic $a$. The attack rate constant (a) is defined as the rate of prey consumption and informs the gradient of the functional response curve whereas the handling time coefficient $(h)$ is the rate of saturation and provides insight as to the time predators spend handling prey between attacks. Together these parameters define the predator's overall functional response. 


\section{Comparing predatory behaviours}

Predatory statistics of attack rates $(a)$ and handling times $(h)$ were calculated and compared using nonlinear least squares regression (as described by Juliano 2001). The number of prey consumed was regressed against the initial density, density ${ }^{2}$ and density ${ }^{3}$. Type I and II responses would be indicated by a significant and negative first order term (density) and a type III response would be indicated by a significant and positive first order (density) and quadratic term $\left(\right.$ density $\left.^{2}\right)$ or a significant third order term (density $\left.{ }^{3}\right)$ (Juliano 2001). Confidence intervals were calculated for each functional response relationship through bootstrapping $(n=999)$. Separate models were fitted for fourth instar larvae and adult predator treatments.

\section{Results}

Prey survival in control treatments, containing no predators or fungal pathogen, was $86.9 \%$, which was significantly higher than predator treatments (H.axyridis $=48.8 \%$, C.septempunctata $=50 \%$ and A.bipunctata $=70.8 \%$ ) (Table 1). Prey mortality was therefore attributed to predatory behaviour of the focal predators. Beauveria bassiana infection was confirmed in $63 \%$ of adult and $48.5 \%$ of larvae infection treatment individuals that died following experiments. $5.9 \%$ of uninfected treatment adults and no larvae showed infection.

The masses of adult ladybird species did not differ between the infection treatment groups (ANOVA; $\left.\mathrm{F}_{2,257}=0.836, P=0.434\right)$ and for each of the three ladybird species, ladybird masses were not significantly different between treatment groups (ANOVA;
$\mathrm{F}_{1,259}=1.117, P=0.291$ ), as a result we did not account for mass in subsequent models. Adults of each species differed significantly in mass (ANOVA; $\left.\mathrm{F}_{2,260}=500.9, P<0.001\right)$ and TukeyHSD results indicated this is driven by $A$. bipunctata (mean $\pm \mathrm{SD}, 9.97 \mathrm{mg} \pm 2.4, \mathrm{n}=89$ ) being significantly smaller than $H$. axyridis (36.05mg $\pm 7.38, \mathrm{n}=88$ ) and C. septempunctata (37.22 $\mathrm{mg} \pm 8.34, \mathrm{n}=86)$. We found no evidence that larvae masses varied significantly with $B$. bassiana infection treatments whether we accounted for species differences or not (ANOVA; $\mathrm{F}_{1,152}=2.912, P=0.09$ and $\left.\mathrm{F}_{1,153}=2.461, P=0.119\right)$. As with adult predators, larval A. bipunctata $(5.87 \mathrm{mg} \pm 2.41, \mathrm{n}=80)$ were significantly smaller than $H$. axyridis (mean $\pm \mathrm{SD}, 19.51 \mathrm{mg} \pm 8.91, \mathrm{n}=76) \quad($ ANOVA; $\left.\mathrm{F}_{1,154}=174.2, P<0.001\right)$.

In adult treatments, the three ladybird species consumed prey at significantly different rates (GLM; $\left.\mathrm{F}_{(2,259)}=11.952, P<0.001\right)$, with invasive $H$. axyridis consuming the most and $A$. bipunctata consuming the least, and more prey were consumed with the increasing prey density treatments (GLM; $\left.\mathrm{F}_{(2,259)}=268.848, \quad P<0.001\right)$. Pathogen exposure did not significantly impact the number of prey consumed by adult ladybirds with each of the interaction terms containing the pathogen treatment (density $*$ species $*$ pathogen, $\quad$ species $*$ pathogen, density $*$ pathogen and density $*$ species) and the main effect all being removed at $P>0.05$. Although ultimately removed from the final model, a marginally significant species * pathogen interaction term $\left(\mathrm{GLM} ; \mathrm{F}_{(2,256)}=2.965, P=0.054\right)$ suggested that the pathogen exposure might have changed the prey consumption of the ladybird species differently. In larval treatments, the number of prey consumed with

Table 1 Results of a logistic regression of the total prey consumed in each prey density treatment for each species

\begin{tabular}{lrrr}
\hline & Coefficient $( \pm$ SE $)$ & t & $P$ \\
\hline Intercept & $-3.266( \pm 2.021)$ & -1.616 & 0.107 \\
Density & $0.689( \pm 0.030)$ & 23.029 & $<0.001 * * *$ \\
Adalia bipunctata & $5.029( \pm 2.023)$ & 2.487 & $0.014 *$ \\
Coccinella septempunctata & $5.708( \pm 2.022)$ & 2.823 & $0.005 * *$ \\
Harmonia axyridis & $5.907( \pm 2.021)$ & 2.922 & $0.004 * *$ \\
\hline
\end{tabular}

Results indicate each species consumed significantly more prey than control treatments in which predators were absent. Prey density was also found to be significant, with more prey consumed at higher prey densities. The analysis was carried out using a quasipoisson error structure with prey density values scaled and centred. Asterisks denote significance of $P$ values; $* P<0.05$; ** $P<0.01$; $* * * P<0.001$ 
increasing density treatment changed significantly when ladybird predators were subject to pathogen exposure $\left(\mathrm{GLM} ; \mathrm{F}_{(1,151)}=1075.8, P=0.010\right)$. Similar to the adult treatments, larvae of the two ladybird species consumed significantly different numbers of prey $\left(\mathrm{GLM} ; \mathrm{F}_{(1,153)},=65.962, P<0.001\right)$, with $H$. axyridis larvae consuming more than $A$. bipunctata larvae. As with the adult ladybird analyses, all other terms were removed from the final model at significance values $(P)$ of more than 0.05 .

Functional responses

All species treatments showed type II functional responses (Fig. 1).

Logistic regression of the proportion of prey consumed against prey density indicated that 7 of the
10 treatments revealed a significant and negative first order term (density) (Supplementary Tables 2a and $2 b$ ), indicating a type II functional response. Two of these analyses showed a significant second order term $\left(\right.$ density $\left.^{2}\right)$, however, these were positive and did not indicate a type III response. No density terms were significant in three treatments; uninfected A. bipunctata and infected $C$. septempunctata adults and infected $H$. axyridis larvae. This could suggest either a type I relationship or that the functional response relationship was undetectable. Further investigation of these treatments using AICc values of the fitted functional response equations (Eqs. 1-3) suggested a type II response for uninfected A. bipunctata adults (Supplementary Table 3). AICc values for infected $C$. septempunctata adults suggested a type III relationship and an indistinguishable type II/III relationship
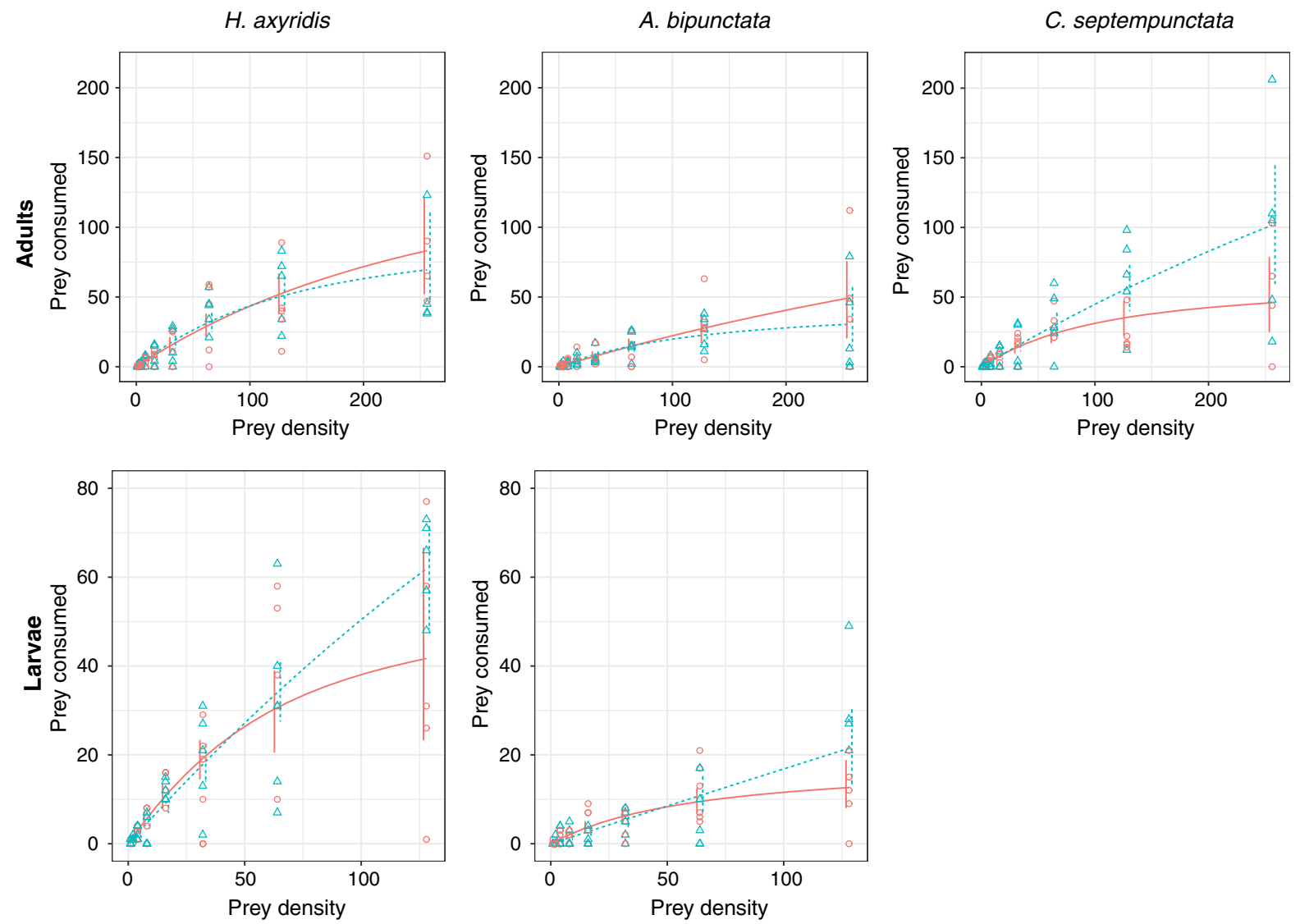

Fig. 1 Predatory functional response curves for three ladybird predators; invasive alien $H$. axyridis (left) and native $A$. bipunctata (middle) and $C$. septempunctata (right) across their adult (top) and larval (bottom) life-stages. Functional response curves (lines) are displayed with replicate data (points; Table 1) and bootstrapped $95 \%$ confidence intervals $(n=999)$ (vertical lines). Uninfected predators (red solid lines and circles) were inoculated with a control dose of Tween 20 and B. bassiana infected predators (blue dashed lines and triangles) were inoculated with a $10^{6}$ suspended spore solution 
for infected $H$. axyridis larvae. Visual inspection of fitted LOESS curves provided qualitatively similar results (Supplementary Figure 1). As the majority of methods and treatments showed type II responses, this was accepted for all species-treatment combinations.

\section{Comparing predatory behaviours}

Visual inspection of functional response curves suggested between-species differences in predatory behaviour, as well as different responses to infection. The functional response curves suggested that $H$. axyridis consumed prey at a higher rate than native $A$. bipunctata and C. septempunctata (Fig. 1) and this was associated with increased attack rate and handling time coefficients which suggest a greater forage ability (Table 2). A similar result was also seen in larval treatments with invasive $H$. axyridis consuming more prey than native $A$. bipunctata (Fig. 1).

Predators responded to $B$. bassiana infection differently, varying with species and life-stage (Table 3). Infected $H$. axyridis and A. bipunctata adults showed lower functional response curves than uninfected conspecifics. In contrast, larval treatments showed the opposite response with infected individuals consuming more prey than uninfected individuals. Adult C. septempunctata showed an opposing response to infection than other adult treatments, instead infected individuals ate more than uninfected individuals. Pathogenic infection also increased the variation in predation, with infected individuals eating at both higher and lower rates than uninfected treatments. In all pairwise comparisons between infected and uninfected treatments, functional response curves differed the most in the higher prey density treatments (Fig. 1).

Predatory behaviour appeared to differ between treatments but as the confidence intervals for the fitted functional response relationships overlapped we explored these relationships further through comparison of predatory statistics [attack rates $(a)$ and handling times $(h)]$. It is important to note that the predatory coefficients ( $a, h$, and maximum feeding rates) are intrinsically linked and combined result in the overall predatory behaviour exhibited by the species. For example, an increase in a predators handling time will result in a decreased maximum feeding rate. Pairwise comparisons of attack rate (a) and handling time (h) showed significant differences between species treatment combinations (Table 2). Species differed significantly with respect to their predatory behaviour with 36 or 42 pairwise comparisons between handling time and attack rate coefficients being significantly different $(P<0.001)$ and in each comparison at least one of the predatory statistics ( $a$ and $h$ ) was significantly different (Table 2).

Within species treatments, $B$. bassiana infection resulted in increased attack rates $(a)$ in adult $H$. axyridis $\quad$ (uninfected $=0.762, \quad$ infected $=1.005$, $\mathrm{z}=-2.696, \quad P=0.007)$ and $A$. bipunctata (uninfected $=0.281, \quad$ infected $=0.392, \quad \mathrm{z}=2.189$, $P=0.029$ ) (Table 3). Adult $C$. septempunctata showed no significant change in attack rate when subjected to pathogen pressure $(P=0.323)$. Conversely, infected ladybird larvae showed lower attack rates in comparison to their uninfected conspecifics (Table 3). However, when adult ladybirds were subjected to pathogen infection $C$. septempunctata showed a shortening of handling times whereas $A$. bipunctata and $H$. axyridis both showed increases (Table 3). Larval treatments of both species showed shorter handling times when exposed to the pathogen (Table 3).

\section{Discussion}

Consistent with our hypothesis, we have shown that a widespread invasive alien predator (Harmonia axyridis) consumes more prey than native Adalia bipunctata and Coccinella septempunctata. The higher consumption rate of $H$. axyridis was linked with better forage ability including higher attack rate and shorter handling time coefficients. Typical efficient predatory behaviour would consist of high rates of attack on prey and short periods of time spent handling and consuming prey. We suggest this per-capita difference in predatory consumption and forage ability between native and IAS could shed light on the documented ecological impacts of $H$. axyridis. Specifically, these attributes could give $H$. axyridis an ecological advantage over native competitors (e.g. other Coccinellidae) and prey (e.g. aphid) species. Previous literature has suggested that the invasive $H$. axyridis is an efficient predator of aphid pests (Xue et al. 2009; Abbott et al. 2014; Wu et al. 2018) and this is likely to have facilitated the species' spread following multiple 
Table 2 Maximum likelihood comparisons of functional response parameters [attack rate $(a)$ and handling time $(h)$ ] between species and treatments

\begin{tabular}{|c|c|c|c|c|c|c|c|c|}
\hline \multirow{2}{*}{$\begin{array}{l}\text { Life stage } \\
\text { Adult }\end{array}$} & \multicolumn{2}{|c|}{ Base species-treatment } & \multicolumn{2}{|c|}{ Contrast species-treatment } & \multirow{2}{*}{$\frac{\text { Metric }}{a}$} & \multirow{2}{*}{$\frac{\text { Estimate }( \pm \mathrm{SE})}{-0.273( \pm 0.06)}$} & \multirow{2}{*}{$\frac{\mathrm{Z}}{-4.520}$} & \multirow{2}{*}{$\frac{P}{<0.001 * * *}$} \\
\hline & Infected & A. bipunctata & Infected & C. septempunctata & & & & \\
\hline & & & & & $h$ & $0.020( \pm 0.003)$ & 6.925 & $<0.001 * * *$ \\
\hline & & & & H. axyridis & $a$ & $-0.614( \pm 0.083)$ & -7.404 & $<0.001 * * *$ \\
\hline & & & & & $h$ & $0.012( \pm 0.003)$ & 4.259 & $<0.001 * * *$ \\
\hline & & & Uninfected & A. bipunctata & $a$ & $0.110( \pm 0.050)$ & 2.189 & $0.029^{*}$ \\
\hline & & & & & $h$ & $0.017( \pm 0.004)$ & 4.834 & $<0.001 * * *$ \\
\hline & & & & C. septempunctata & $a$ & $-0.354( \pm 0.083)$ & -4.284 & $<0.001 * * *$ \\
\hline & & & & & $h$ & $0.006( \pm 0.003)$ & 1.943 & 0.052 \\
\hline & & & & H. axyridis & $a$ & $-0.371( \pm 0.070)$ & -5.280 & $<0.001 * * *$ \\
\hline & & & & & $h$ & $0.016( \pm 0.003)$ & 5.628 & $<0.001 * * *$ \\
\hline & & C. septempunctata & Infected & H. axyridis & $a$ & $-0.342( \pm 0.083)$ & -4.128 & $<0.001 * * *$ \\
\hline & & & & & $h$ & $-0.008( \pm 0.001)$ & -7.138 & $<0.001 * * *$ \\
\hline & & & Uninfected & A. bipunctata & $a$ & $0.383( \pm 0.050)$ & 7.642 & $<0.001 * * *$ \\
\hline & & & & & $h$ & $-0.003( \pm 0.002)$ & -1.036 & 0.300 \\
\hline & & & & C. septempunctata & $a$ & $-0.082( \pm 0.083)$ & -0.989 & 0.323 \\
\hline & & & & & $h$ & $-0.014( \pm 0.002)$ & -8.105 & $<0.001 * * *$ \\
\hline & & & & H. axyridis & $a$ & $-0.097( \pm 0.070)$ & -1.392 & 0.164 \\
\hline & & & & & $h$ & $-0.004( \pm 0.001)$ & -3.168 & $0.002 * *$ \\
\hline & Uninfected & A. bipunctata & Infected & H. axyridis & $a$ & $-0.724( \pm 0.076)$ & -9.553 & $<0.001 * * *$ \\
\hline & & & & & $h$ & $-0.005( \pm 0.002)$ & -2.099 & $0.036^{*}$ \\
\hline & & & Uninfected & C. septempunctata & $a$ & $-0.464( \pm 0.076)$ & -6.147 & $<0.001 * * *$ \\
\hline & & & & & $h$ & $-0.011( \pm 0.003)$ & -4.075 & $<0.001 * * *$ \\
\hline & & & & H. axyridis & $a$ & $-0.481( \pm 0.061)$ & -7.802 & $<0.001 * * *$ \\
\hline & & & & & $h$ & $-0.001( \pm 0.002)$ & -0.409 & 0.683 \\
\hline & & C. septempunctata & Infected & H. axyridis & $a$ & $-0.259( \pm 0.100)$ & -2.586 & $0.010 * *$ \\
\hline & & & & & $h$ & $0.006( \pm 0.002)$ & 3.544 & $<0.001 * * *$ \\
\hline & & & Uninfected & H. axyridis & $a$ & $-0.017( \pm 0.090)$ & -0.183 & 0.855 \\
\hline & & & & & $h$ & $0.010( \pm 0.002)$ & 5.797 & $<0.001 * * *$ \\
\hline & & H. axyridis & Infected & H. axyridis & $a$ & $-0.243( \pm 0.090)$ & -2.696 & $0.007 * *$ \\
\hline & & & & & $h$ & $-0.004( \pm 0.001)$ & -3.475 & $<0.001^{* * *}$ \\
\hline \multirow[t]{12}{*}{ Larvae } & Infected & H. axyridis & Infected & A. bipunctata & $a$ & $0.781( \pm 0.079)$ & 9.929 & $<0.001 * * *$ \\
\hline & & & & & $h$ & $0.052( \pm 0.013)$ & 3.900 & $<0.001 * * *$ \\
\hline & & & Uninfected & A. bipunctata & $a$ & $0.546( \pm 0.095)$ & 5.747 & $<0.001 * * *$ \\
\hline & & & & & $h$ & $-0.050( \pm 0.010)$ & -4.829 & $<0.001 * * *$ \\
\hline & & & & H. axyridis & $a$ & $-0.486( \pm 0.151)$ & -3.219 & $0.001 * *$ \\
\hline & & & & & $h$ & $-0.013( \pm 0.002)$ & -5.833 & $<0.001 * * *$ \\
\hline & Uninfected & H. axyridis & Infected & A. bipunctata & $a$ & $0.816( \pm 0.078)$ & 10.545 & $<0.001 * * *$ \\
\hline & & & & & $h$ & $0.049( \pm 0.012)$ & 4.276 & $<0.001 * * *$ \\
\hline & & & Uninfected & A. bipunctata & $a$ & $1.033( \pm 0.143)$ & 7.237 & $<0.001 * * *$ \\
\hline & & & & & $h$ & $-0.037( \pm 0.011)$ & -3.574 & $<0.001 * * *$ \\
\hline & Uninfected & A. bipunctata & Infected & A. bipunctata & $a$ & $0.224( \pm 0.060)$ & 3.770 & $<0.001 * * *$ \\
\hline & & & & & $h$ & $0.103( \pm 0.017)$ & 6.079 & $<0.001 * * *$ \\
\hline
\end{tabular}

Functional response parameters were calculated through the fitting of the Rogers' 'random predator' type II functional response equation (Eq. 2). Maximum likelihood comparisons are made using methods described by Juliano (2001). Asterisks denote significance of $P$ values; $* P<0.05 ; * * P<0.01 ; * * * P<0.001$ 
Table 3 Comparison of predicted attack rate $(a)$ and handling time $(h)$ coefficients between infected and uninfected predator treatments

\begin{tabular}{|c|c|c|c|c|c|}
\hline Life-stage & Species & Metric & Uninfected $( \pm \mathrm{SE})$ & Infected $( \pm$ SE) & $P$ \\
\hline \multirow[t]{6}{*}{ Adult } & \multirow[t]{2}{*}{ A. bipunctata } & $a$ & $0.281( \pm 0.027)$ & $0.392( \pm 0.043)$ & $0.029 *$ \\
\hline & & $h$ & $0.005( \pm 0.002)$ & $0.022( \pm 0.003)$ & $<0.001 * * *$ \\
\hline & \multirow[t]{2}{*}{ C. septempunctata } & $a$ & $0.746( \pm 0.071)$ & $0.664( \pm 0.042)$ & 0.323 \\
\hline & & $h$ & $0.016( \pm 0.002)$ & $0.002( \pm 0.001)$ & $<0.001 * * *$ \\
\hline & \multirow[t]{2}{*}{ H. axyridis } & $a$ & $0.762( \pm 0.056)$ & $1.005( \pm 0.071)$ & $0.007 * *$ \\
\hline & & $h$ & $0.006( \pm 0.001)$ & $0.010( \pm 0.001)$ & $<0.001 * * *$ \\
\hline \multirow[t]{4}{*}{ Larvae } & \multirow[t]{2}{*}{ A. bipunctata } & $a$ & $0.333( \pm 0.057)$ & $0.192( \pm 0.023)$ & $0.032 *$ \\
\hline & & $h$ & $0.054( \pm 0.010)$ & $0.003( \pm 0.009)$ & $<0.001 * * *$ \\
\hline & \multirow[t]{2}{*}{ H. axyridis } & $a$ & $1.366( \pm 0.131)$ & $0.879( \pm 0.076)$ & $0.001 * *$ \\
\hline & & $h$ & $0.017( \pm 0.002)$ & $0.004( \pm 0.002)$ & $<0.001 * * *$ \\
\hline
\end{tabular}

Coefficients were calculated by fitting Rogers' 'random predator' type II functional response equation (Eq. 2) and compared using maximum likelihood. Asterisks denote significance of $P$ values; $* P<0.05 ; * * P<0.01 ; * * * P<0.001$

releases as a biological control agent. We show that $H$. axyridis is indeed an effective predator, in keeping with our initial hypothesis and previous literature.

Predatory behaviours differ between species

We have also provided evidence that the two larger ladybird species (H. axyridis and C. septempunctata) were more similar, with respect to their predation rates, than the smaller $A$. bipunctata. These findings are consistent with both our hypotheses and the wider literature. For example, Xue et al. (2009) show that $H$. axyridis and $C$. septempunctata both show type II functional responses when provided with soybean aphids (Aphis glycines) during larval and adult life stages. Similarly, Jalali et al. (2010) provide evidence that adult $A$. bipunctata also show a type II functional response curves when provided a diet of pea aphids (Acyrthosiphon pisum). As far as we are aware, we are among the first to compare the predatory abilities of $H$. axyridis, C. septempunctata, and A. bipunctata and to consider both adult and larval life-stages. Furthering our understanding as to the relative predatory abilities of these three species is important to understand the potential impacts of $H$. axyridis on native ladybird species, through competition and intra-guild predation, and native prey sources (e.g. aphids), through predation. We suggest that the predatory behaviour of $H$. axyridis could, at least in part, be due to their size. Invasive $H$. axyridis and native $C$. septempunctata are both large ladybirds and were found to be generally more similar in their predatory behaviours than the smaller native A. bipunctata, which consumed prey at lower rates than both larger species. Features that facilitate more efficient predatory behaviour are known to scale with predator size. For example, size commonly correlates with greater predator speed, which can increase predator attack rates, and less time spent consuming and digesting prey, which will reduce a predators handling time (Woodward and Warren 2007; Gergs and Ratte 2009). A similar relationship was also noted in larval treatments, with $H$. axyridis and A. bipunctata predatory behaviours being significantly different. Metabolic theory, as discussed by Brown et al. (2004), suggests that the energetic demands of an organism is correlated with the organism's mass. While this is in keeping with our findings, no further investigation of the relationship between consumption rate and predator mass was undertaken as while $H$. axyridis and $C$. septempunctata do overlap with respect to their masses, neither overlap with the masses of A. bipunctata and this would result in complete separation in statistical analyses.

Pathogenic infection changes predatory ability

For the first time, to our knowledge, we also show the impact of a widespread pathogen on the predatory ability of ladybirds and, specifically, how this impacts the relative predatory abilities of native and invasive ladybirds. Beauveria bassiana infection resulted in significant changes in predator forage ability. Invasive alien $H$. axyridis and native $A$. bipunctata adults 
showed an increase in attack rate and handling time coefficients when exposed to the pathogen. While an increase in the attack rate coefficient would suggest an increase in prey consumption, the increase in the handling time coefficient would suggest the opposite with the predator spending more time handling and consuming prey individuals. Visual inspection of the functional response relationship shows these coefficients result in a lower overall functional response curve. Contrary to our expectations, native $C$. septempunctata adults showed reduced prey handling times when exposed to the pathogen and no significant change in attack rates. Both larval treatments $(H$. axyridis and $A$. bipunctata) demonstrated significantly reduced attack rate and handling time coefficients when subject to the pathogen treatment. It could have been expected that the ladybird species would have responded differently to $B$. bassiana due to their different evolutionary histories with the pathogen. For example, native ladybird species are likely to have an evolutionary history with $B$. bassiana and are therefore more likely to have behavioural or chemical defences while non-native species are more likely to be naïve to the novel pathogen (Hatcher and Dunn 2011). Evidence for this hypothesis is the fact that $B$. bassiana is a significant cause of $C$. septempunctata overwintering mortality and, while unable to demonstrate such avoidance behaviours within this experiment, $C$. septempunctata are known to avoid $B$. bassiana infected cadavers in the field (Ormond et al. 2011). It is also likely that B. bassiana infection could persist within $C$. septempunctata populations and therefore impact behaviours, such a predation, as we have described here. However, H. axyridis is known to have a highly efficient immune system, consisting of antimicrobial peptides, which results in $H$. axyridis being less susceptible to many natural enemies including bacteria, fungi, yeasts, and parasitoid flies and wasps (Roy et al. 2008b; Berkvens et al. 2010; Gross et al. 2010; Vilcinskas et al. 2013; Verheggen et al. 2017; Ceryngier et al. 2018; Gegner et al. 2018). Gross et al. (2010) report that the antimicrobial activity of $H$. axyridis hemolymph was approximately one thousand times greater than $C$. septempunctata hemolymph. It is likely that this defence against natural enemies will have facilitated the spread of $H$. axyridis, in addition to other features of the species, such as high predatory ability.
Beauveria bassiana infection resulted in different outcomes for adult and larval life-stages. It is possible that $B$. bassiana infection, through its hyphal growth throughout the host, would impose physiological damage that would impede the predatory ability of individuals, resulting in reduced prey consumption, attack rates and an increase in handling times. However, predatory behaviour may either increase, as the host attempts to mitigate the costs of infection (for example Dick et al. 2010; Bunke et al. 2015), or decrease as the costs of infection rise from either the damage or increased metabolic demand associated with the infection process (for example, MacNeil et al. 2003; Haddaway et al. 2012; Toscano et al. 2014). We suggest that the physiological damage and increased metabolic demand resulted in a decreased ability to consume prey in adult treatments whereas the mechanism driving the observed changes in infected larvae is less clear. We suggest that desiccation or other fungal, viral or bacterial infections could be a contributing factor. Upon infection, B. bassiana conidia germinate and penetrate the hosts outer integument before commencing extensive hyphal growth throughout the host's internal cavity. Vey and Jacques (1977) and Poprawski et al. (1999) suggest the repeated penetration of the outer cuticle or soft body of the host can result in an increased risk of desiccation and subsequent infections which would result in additional costs to the host and subsequently affect the host's predatory behaviours. We suggest the larvae are responding to these increased costs, specifically desiccation, by increasing their consumption rates however, further investigation would be required to explicitly establish this relationship.

Implications for invaded communities

In light of our findings, we propose that the invasion of $H$. axyridis is likely to have imposed an increased level of novel predatory pressure on prey species (e.g. aphids) and indirect effects on competitors (e.g. other Coccinellidae). While $B$. bassiana is known to result in approximately $10-15 \%$ C. septempunctata overwintering mortality (Ormond et al. 2006), instances of infection in $H$. axyridis and $A$. bipunctata are considered rare. We suggest our findings are of interest with respect to current field interactions, for example the predatory differences between the three Coccinellidae, and the impact B. bassiana has on the predatory ability 
of $C$. septempunctata, but also within a more theoretical framework whereby interactions between $H$. axyridis, A. bipunctata, and B. bassiana become more frequent than is currently documented. Harmonia axyridis is known to be highly abundant and commonly dominates invaded Coccinellidae assemblages (Brown and Roy 2017), it is likely therefore that the per-capita differences identified here will scale up and result in larger community impacts in field populations as $H$. axyridis' numerical response to prey density is taken into account (see Dick et al. 2017b). While not quantified here, the numerical response, a measure of how predator abundance changes with respect to changes in prey abundance, is likely to impact native prey in a similar way the the predators per capita functional response. Accounting for the demographics of wild populations is essential to further our understanding of any potential impacts posed by a predator and overcome limitations within functional response studies. For example, functional response studies do not commonly account for prey switching which could otherwise be expected in natural communities. However, it has been suggested that generalist predators, such as Coccinellidae, are likely to show less pronounced prey switching than predators foraging on a fewer prey (Van Leeuwen et al. 2013). Additionally, measures of predatory behaviour attained through functional response studies rely on those focal individuals being representative of the wider predator community. The Coccinellid predators used as part of this study were all of similar ages (fourth instar larvae or recently emerged adults) however, it could be expected that unhealthy or otherwise suboptimal individuals, including those becoming increasingly moribund, could show lower rates of predatory behaviour.

It is likely that $H$. axyridis will impact some species more than others, for example Roy et al. (2012) attribute the decline of native A. bipunctata (44\% in Britain and $30 \%$ in Belgium) to the arrival and subsequent spread of $H$. axyridis. In contrast, $C$. septempunctata populations showed no significant change. Kenis et al. (2017) use a collection of risk measures (for example, the likelihood of encountering $H$. axyridis) to predict the native species most at risk from $H$. axyridis. Native $A$. bipunctata were identified as being at 'very high' risk while native $C$. septempunctata were identified as being at 'medium risk'. We have shown $H$. axyridis to be an efficient predator which, when compared to additional characteristics of the species, could further our understanding as to how $H$. axyridis impacts native communities. For example, in addition to being a relatively large ladybird (Hodek et al. 2012) and consuming a wide variety of prey species (see Roy and Brown 2015), including engaging in specialised predatory behaviours (e.g. Intraguild predation; e.g. Pell et al. 2008), we have provided further evidence as to the efficient predatory ability of $H$. axyridis. We also suggest the increased predatory behaviour exhibited by $H$. axyridis could have facilitated the species' initial spread and continued success throughout its invaded range.

\section{Concluding remarks}

We have provided evidence that pathogenic infection impacted the predatory behaviour of ladybirds in a species and life-stage specific way. Despite being known to mediate invasion success and impact through their lethal and sub-lethal effects (Dunn et al. 2012; Strauss et al. 2012), the effects of parasites and pathogens are rarely accounted for within invasion ecology regardless of literature showing that their impacts can vary. For example, invasive Gammarus pulex harbouring acanthocephalan infection show increased intake of prey (Dick et al. 2010). Conversely, infection has also been shown to result in reduced consumption rates (Wright et al. 2006; Toscano et al. 2014). While instances of infection by native parasites and pathogens may be low in $H$. axyridis, due to its efficient immune system, understanding how infection can modify the key functional behaviours of this widespread invasive alien species is key to furthering our understanding of the effects of infection on the success and impacts of invasion events (Brook et al. 2008; Strayer 2010). Here we demonstrate that pathogenic infection affects a key functional trait, predation, of $H$. axyridis and two native species (A. bipunctata and C. septempunctata).

We have shown that the invasive alien $H$. axyridis displays significantly more efficient predatory behaviour than two native predators in both adult and larval life-stages. Pathogenic infection significantly changed the foraging ability of ladybird predators in a species and life-stage specific way but resulted in no measurable change in overall prey consumption. We suggest the impacts of $H$. axyridis are at least partially 
explained by the more efficient predatory behaviour detailed here.

Acknowledgements The authors would like to thank Katie Berry for supplying Botaniguard WP and Gary Needham for supplying the T. aestivum seeds. We also thank two anonymous reviewers for the helpful comments on an earlier draft of this manuscript. William Fincham is supported by a NERC studentship (NE/L002574/1) with support from the Centre for Ecology \& Hydrology.

\section{Compliance with ethical standards}

Author contributions WF, AD, LB, HH, and HR designed the experiment. WF and $\mathrm{HH}$ collected the data. WF analysed the data and wrote the manuscript. All authors critiqued the manuscript for intellectual content.

Open Access This article is distributed under the terms of the Creative Commons Attribution 4.0 International License (http:// creativecommons.org/licenses/by/4.0/), which permits unrestricted use, distribution, and reproduction in any medium, provided you give appropriate credit to the original author(s) and the source, provide a link to the Creative Commons license, and indicate if changes were made.

\section{References}

Abbott KC, Harmon JP, Fabina NS (2014) The challenge of predicting temperature effects on short-term predator-prey dynamics. Popul Ecol 56(2):375-392. https://doi.org/10. 1007/s10144-013-0426-x

Alexander ME, Dick JTA, Weyl OLF, Robinson TB, Richardson DM (2014) Existing and emerging high impact invasive species are characterized by higher functional responses than natives. Biol Lett 10:20130946. https://doi. org/10.1098/rsbl.2013.0946

Bahlai CA, Colunga-Garcia M, Gage SH, Landis DA (2014) The role of exotic ladybeetles in the decline of native ladybeetle populations: evidence from long-term monitoring. Biol Invasions 17:1005-1024. https://doi.org/10. 1007/s10530-014-0772-4

Bellard C, Cassey P, Blackburn TM (2016) Alien species as a driver of recent extinctions. Biol Lett 12(2):20150623. https://doi.org/10.1098/rsbl.2015.0623

Berkvens N, Moens J, Berkvens D, Samih MA, Tirry L, De Clercq P (2010) Dinocampus coccinellae as a parasitoid of the invasive ladybird Harmonia axyridis in Europe. Biol Control 53:92-99. https://doi.org/10.1016/j.biocontrol. 2009.11.001

Bolker BM (2016) emdbook: ecological models and data analysis in R. R package. https://ms.mcmaster.ca/ bolker/ emdbook/. Accessed 10 Jan 2016

Bolker B, R Development Core Team (2014) bbmle: tools for general maximum likelihood estimation. http://cran.rproject.org/package=bbmle. Accessed 10 Jan 2016
Brook BW, Sodhi NS, Bradshaw CJA (2008) Synergies among extinction drivers under global change. Trends Ecol Evol 23(8):453-460. https://doi.org/10.1016/j.tree.2008.03.011

Brown PMJ, Roy HE (2017) Native ladybird decline caused by the invasive harlequin ladybird Harmonia axyridis: evidence from a long-term field study. Insect Conserv Divers. https://doi.org/10.1111/icad.12266

Brown JH, Gillooly JF, Allen AP, Savage VM, West GB (2004) Toward a metabolic theory of ecology. Ecology 85(7):1771-1789. https://doi.org/10.1890/03-9000

Bunke M, Alexander ME, Dick JTA, Hatcher MJ, Paterson RA, Dunn AM (2015) Eaten alive: cannibalism is enhanced by parasites. R Soc Lond 2(3):140369. https://doi.org/10. 1098/rsos. 140369

Camacho-cervantes M, Ortega-iturriaga A (2017) From effective biocontrol agent to successful invader: the harlequin ladybird (Harmonia axyridis) as an example of good ideas that could go wrong. PeerJ 5:e3296. https://doi.org/10. 7717/peerj.3296

Ceryngier P, Nedvěd O, Grez AA, Riddick EW, Roy HE, San Martin G, Steenberg T, Veselý P, Zaviezo T, ZúñigaReinoso Á, Haelewaters D (2018) Predators and parasitoids of the harlequin ladybird, Harmonia axyridis, in its native range and invaded areas. Biol Invasions 20(4):1009-1031. https://doi.org/10.1007/s10530-017-1608-9

Cottrell TE, Shapiro-Ilan DI (2003) Susceptibility of a native and an exotic lady beetle (Coleoptera: Coccinellidae) to Beauveria bassiana. J Invertebr Pathol 84:137-144. https://doi.org/10.1016/j.jip.2003.09.003

Cuthbert RN, Dick JT, Callaghan A, Dickey JW (2018) Biological control agent selection under environmental change using functional responses, abundances and fecundities; the Relative Control Potential (RCP) metric. Biol Control 121(February):50-57. https://doi.org/10.1016/j.biocontrol. 2018.02.008

Dick JTA, Armstrong M, Clarke HC, Farnsworth KD, Hatcher MJ, Ennis M, Kelly A, Dunn AM (2010) Parasitism may enhance rather than reduce the predatory impact of an invader. Biol Lett 6:636-638

Dick JT, Gallagher K, Avlijas S, Clarke HC, Lewis SE, Leung S, Minchin D, Caffrey J, Alexander ME, Maguire C, Harrod C, Reid N, Haddaway NR, Farnsworth KD, Penk M, Ricciardi A (2013) Ecological impacts of an invasive predator explained and predicted by comparative functional responses. Biol Invasions 15(4):837-846. https://doi.org/ 10.1007/s10530-012-0332-8

Dick JTA, Alexander ME, Ricciardi A, Laverty C, Paul O, Xu M, Jeschke JM, Saul WC, Hill MP, Neill DBO, Weyl OLF, Shaw RH (2017a) Functional responses can unify invasion ecology. Biol Invasions 5(19):1667-1672. https://doi.org/ 10.1007/s10530-016-1355-3

Dick JTA, Laverty C, Lennon JJ, Barrios-O’Neill D, Mensink PJ, Britton JR, Médoc V, Boets P, Alexander ME, Taylor NG, Dunn AM, Hatcher MJ, Rosewarne PJ, Crookes S, MacIsaac HJ, Xu M, Ricciardi A, Wasserman RJ, Ellender BR, Weyl OLF, Lucy FE, Banks PB, Dodd JA, MacNeil C, Penk MR, Aldridge DC, Caffrey JM (2017b) Invader Relative Impact Potential: a new metric to understand and predict the ecological impacts of existing, emerging and future invasive alien species. $J$ Appl Ecol 
54(4):1259-1267. https://doi.org/10.1111/1365-2664. 12849

Doherty TS, Glen AS, Nimmo DG, Ritchie EG, Dickman CR (2016) Invasive predators and global biodiversity loss. Proc Natl Acad Sci 113(40):11261-11265. https://doi.org/ 10.1073/pnas. 1602480113

Dunn AM, Hatcher MJ (2015) Parasites and biological invasions: parallels, interactions, and control. Trends Parasitol 31(5):189-199. https://doi.org/10.1016/j.pt.2014.12.003

Dunn AM, Torchin ME, Hatcher MJ, Kotanen PM, Blumenthal DM, Byers JE, Coon CAC, Frankel VM, Holt RD, Hufbauer RA, Kanarek AR, Schierenbeck KA, Wolfe LM, Perkins SE (2012) Indirect effects of parasites in invasions. Funct Ecol 26(6):1262-1274. https://doi.org/10.1111/j. 1365-2435.2012.02041.x

Gegner T, Schmidtberg H, Vogel H, Vilcinskas A (2018) Population-specific expression of antimicrobial peptides conferring pathogen resistance in the invasive ladybird Harmonia axyridis. Sci Rep 8(1):1-7. https://doi.org/10. 1038/s41598-018-21781-4

Gergs A, Ratte HT (2009) Predicting functional response and size selectivity of juvenile Notonecta maculata foraging on Daphnia magna. Ecol Model 220(23):3331-3341. https:// doi.org/10.1016/j.ecolmodel.2009.08.012

Grez AA, Zaviezo T, Roy HE, Brown PMJ, Bizama G (2016) Rapid spread of Harmonia axyridis in Chile and its effects on local coccinellid biodiversity. Divers Distrib 22:982-994

Gross J, Eben A, Müller I, Wensing A (2010) Awell protected intruder: the effective antimicrobial defense of the invasive ladybird Harmonia axyridis. J Chem Ecol 36(11):1180-1188. https://doi.org/10.1007/s10886-0109867-2

Gupta R, Pervez A, Guroo M, Srivastava K (2012) Stagespecific functional response of an aphidophagous ladybird, Coccinella septempunctata (Coleoptera: Coccinellidae), to two aphid species. Int J Trop Insect Sci 32(03):136-141. https://doi.org/10.1017/S1742758412000227

Haddaway NR, Wilcox RH, Heptonstall REA, Griffiths HM, Mortimer RJG, Christmas M, Dunn AM (2012) Predatory functional response and prey choice identify predation differences between native/invasive and parasitised/unparasitised crayfish. PLoS ONE 7(2):e32229. https://doi. org/10.1371/journal.pone.0032229

Haelewaters D, Zhao SY, Ted SCT, Luka DK, Herz A, Hesketh H, Hui C, Kleespies RG, Losey JE, Minnaar IA, Murray KM, Rebecca DISI, Tove RS, Paul S, Zhao Z, Ceryngier P, Roy HE (2017) Parasites of Harmonia axyridis: current research and perspectives. BioControl 62:355-371. https:// doi.org/10.1007/s10526-016-9766-8

Haelewaters D, Shapiro-Ilan DI, Cottrell TE (2018) Will dual fungal infections increase Harmonia axyridis mortality in natural populations? IOBC-WPRS Bull 137(September):12-16

Harmon JP, Stephens E, Losey J (2007) The decline of native coccinellids (Coleoptera: Coccinellidae) in the United States and Canada. J Insect Conserv 11:85-94

Hassell MP (1978) The dynamics of arthropod predator-prey systems. In: Hassell MP (ed) Functional responses. Princeton University Press, Princeton, pp 28-49
Hatcher M, Dunn A (2011) Parasites in ecological communities: from interactions to ecosystems. Cambridge University Press, Cambridge

Hatcher MJ, Dick JT, Dunn AM (2012) Diverse effects of parasites in ecosystems: linking interdependent processes. Front Ecol Environ 10(4):186-194. https://doi.org/10. $1890 / 110016$

Hatcher MJ, Dick JTA, Dunn AM (2014) Parasites that change predator or prey behaviour can have keystone effects on community composition. Biol Lett 10:20130879

Hodek I, van Emden HF, Honěk A (eds) (2012) Ecology and behaviour of the ladybird beetles (Coccinellidae). WileyBlackwell Publishing, Chicester

Holling CS (1959) Some characteristics of simple types of predation and parasitism. Can Entomol 91(7):385-398

Honek A, Martinkova Z, Evans EW, Skuhrovec J (2017) Estimating prey consumption in natural populations of Harmonia axyridis (Coleoptera: Coccinellidae) using production of feces. J Econ Entomol 110(6):2406-2412. https://doi.org/10.1093/jee/tox294

Howe AG, Ravn HP, Jensen AB, Meyling NV (2016) Spatial and taxonomical overlap of fungi on phylloplanes and invasive alien ladybirds with fungal infections in tree crowns of urban green spaces. FEMS Microbiol Ecol 92(9):1-11. https://doi.org/10.1093/femsec/fiw143

Hulme PE (2009) Trade, transport and trouble: managing invasive species pathways in an era of globalization. J Appl Ecol 46(1):10-18

Iltis C, Spataro T, Wattier R, Médoc V (2018) Parasitism may alter functional response comparisons: a case study on the killer shrimp Dikerogammarus villosus and two non-invasive gammarids. Biol Invasions 20(3):619-632. https:// doi.org/10.1007/s10530-017-1563-5

Jalali MA, Tirry L, de Clercq P (2010) Effect of temperature on the functional response of Adalia bipunctata to Myzus persicae. BioControl 55(2):261-269. https://doi.org/10. 1007/s10526-009-9237-6

Juliano SA (2001) Nonlinear curve fitting: predation and functional response curves. In: Scheiner SM, Gurevitch J (eds) Design and analysis of ecological experiment, 2nd edn. Oxford University Press, New York, pp 178-196

Katsanis A, Babendreier D, Nentwig W, Kenis M (2013) Intraguild predation between the invasive ladybird Harmonia axyridis and non-target European coccinellid species. BioControl 58(1):73-83. https://doi.org/10.1007/ s10526-012-9470-2

Kenis M, Adriaens T, Brown PMJ, Katsanis A, Martin GS, Branquart E, Maes D, Eschen R, Zindel R, van Vlaenderen J, Babendreier D, Roy HE, Hautier L, Poland RL (2017) Assessing the ecological risk posed by a recently established invasive alien predator: Harmonia axyridis as a case study. BioControl 62:341-354. https://doi.org/10.1007/ s10526-016-9764-x

Koch RL, Galvan TL (2008) Bad side of a good beetle: the North American experience with Harmonia axyridis. Biocontrol 53:23-35. https://doi.org/10.1007/978-1-4020-6939-0_3

Koch R, Hutchison W, Venette R, Heimpel G (2003) Susceptibility of immature monarch butterfly, Danaus plexippus (Lepidoptera: Nymphalidae: Danainae), to predation by Harmonia axyridis (Coleoptera: Coccinellidae). Biol 
Control 28(2):265-270. https://doi.org/10.1016/S10499644(03)00102-6

Koyama S, Majerus MEN (2007) Interactions between the parasitoid wasp Dinocampus coccinellae and two species of coccinellid from Japan and Britain. BioControl 53(1):253-264. https://doi.org/10.1007/s10526-007-91385

Laverty C, Green KD, Dick JTA, Barrios-O'Neill D, Mensink PJ, Médoc V, Spataro T, Caffrey JM, Lucy FE, Boets P, Britton JR, Pegg J, Gallagher C (2017) Assessing the ecological impacts of invasive species based on their functional responses and abundances. Biol Invasions 19(5):1653-1665. https://doi.org/10.1007/s10530-0171378-4

Levine JM, D'Antonio CM (2003) Forecasting biological invasions with increasing international trade. Conserv Biol 17(1):322-326. https://doi.org/10.1046/j.1523-1739.2003. 02038.x

MacNeil C, Fielding NJ, Hume Kevin D, Dick JT, Elwood RW, Hatcher MJ, Dunn AM (2003) Parasite altered micro-distribution of Gammarus pulex (Crustacea: Amphipoda). Int J Parasitol 33:57-64. https://doi.org/10.1016/S00207519(02)00229-1

Majerus M, Strawson V, Roy H (2006) The potential impacts of the arrival of the harlequin ladybird, Harmonia axyridis (Pallas) (Coleoptera: Coccinellidae), in Britain. Ecol Entomol 31(3):207-215

McCornack BP, Koch RL, Ragsdale DW (1980) A simple method for in-field sex determination of the multicolored Asian lady beetle Harmonia axyridis. J Insect Sci 7(10):1-12

Meyling NV, Eilenberg J (2006) Isolation and characterisation of Beauveria bassiana isolates from phylloplanes of hedgerow vegetation. Mycol Res 110(2):188-195. https:// doi.org/10.1016/j.mycres.2005.09.008

Murdoch W, Oaten A (1975) Predation and population stability. Adv Ecol Res 9:1-131

O’Neill RJ (1990) Functional response of arthropod predators and its role in the biological control of insect pests in agricultural systems. In: Dunn PE, Baker RR (eds) New directions in biological control. Alternatives for suppressing agricultural pests and diseases. Alan R. Liss Inc., New York, pp 83-96

Ormond EL, Thomas APM, Pell JK, Roy HE (2006) Overwintering ecology of Coccinella septempunctata. Beauveria bassiana and Dinocampus coccinellae. Tech. rep, IOBC/ WPRS Bulletin

Ormond EL, Thomas AP, Pugh PJ, Pell JK, Roy HE (2010) A fungal pathogen in time and space: the population dynamics of Beauveria bassiana in a conifer forest. FEMS Microbiol Ecol 74(1):146-154. https://doi.org/10.1111/j. 1574-6941.2010.00939.x

Ormond EL, Thomas APM, Pell JK, Freeman SN, Roy HE (2011) Avoidance of a generalist entomopathogenic fungus by the ladybird, Coccinella septempunctata. FEMS Microbiol Ecol 77(2):229-237. https://doi.org/10.1111/j. 1574-6941.2011.01100.x

Pell JK, Baverstock J, Roy HE, Ware RL, Majerus MEN (2008) Intraguild predation involving Harmonia axyridis: a review of current knowledge and future perspectives. BioControl 53(1):147-168
Pfliegler WP, Báthori F, Wang TW, Tartally A, Haelewaters D (2018) Herpomyces ectoparasitic fungi (Ascomycota, Laboulbeniales) are globally distributed by their invasive cockroach hosts and through the pet trade industry. Mycologia 110(1):39-46. https://doi.org/10.1080/ 00275514.2017 .1418567

Poprawski TJ, Parker PE, Tsai JH (1999) Laboratory and field evaluation of hyphomycete insect pathogenic fungi for control of brown citrus aphid (Homoptera: Aphididae). Environ Entomol 28(2):315-321

R Core Team (2016) Computing, R: a language and environment for statistical computing. http://www.r-project.org/. Accessed 10 Jan 2016

Rogers D (1972) Random search and insect population models. J Anim Ecol 41(2):369-383

Roy HE, Brown PMJ (2015) Ten years of invasion: Harmonia axyridis (Pallas) (Coleoptera: Coccinellidae) in Britain. Ecol Entomol. https://doi.org/10.1111/een.12203

Roy HE, Baverstock J, Ware RL, Clark SJ, Majerus MEN, Baverstock KE, Pell JK (2008a) Intraguild predation of the aphid pathogenic fungus Pandora neoaphidis by the invasive coccinellid Harmonia axyridis. Ecol Entomol 33:175-182

Roy HE, Brown PMJ, Rothery P (2008b) Interactions between the fungal pathogen Beauveria bassiana and three species of ladybird: Harmonia axyridis, Coccinella septempunctata and Adalia bipunctata. BioControl 53:265-276

Roy HE, Brown PMJ, Frost R, Poland R (2011) Ladybirds (Coccinellidea) of Britain and Ireland. FSC Publications, Shrewsbury

Roy HE, Adriaens T, Isaac NJB, Kenis M, Onkelinx T, Martin GS, Brown PMJ, Hautier L, Poland R, Roy DB, Comont R, Eschen R, Frost R, Zindel R, Van Vlaenderen J, Nedvěd O, Ravn HP, Grégoire JC, de Biseau JC, Maes D (2012) Invasive alien predator causes rapid declines of native European ladybirds. Divers Distrib 18(7):717-725

Roy HE, Brown PMJ, Comont RF, Poland RL, Sloggett JJ, Allington S, Shields C (2013) Ladybirds (naturalists handbook), 2nd edn. Pelagic Publishing, Exeter

Roy HE, Brown PMJ, Adriaens T, Berkvens N, Borges I, Clusella-Trullas S, Comont RF, De Clercq P, Eschen R, Estoup A, Evans EW, Facon B, Gardiner MM, Gil A, Grez AA, Guillemaud T, Haelewaters D, Herz A, Honek A, Howe AG, Hui C, Hutchison WD, Kenis M, Koch RL, Kulfan J, Lawson Handley L, Lombaert E, Loomans A, Losey J, Lukashuk AO, Maes D, Magro A, Murray KM, Martin GS, Martinkova Z, Minnaar IA, Nedved O, Orlova-Bienkowskaja MJ, Osawa N, Rabitsch W, Ravn HP, Rondoni G, Rorke SL, Ryndevich SK, Saethre MG, Sloggett JJ, Soares AO, Stals R, Tinsley MC, Vandereycken A, van Wielink P, Viglášová S, Zach P, Zakharov IA, Zaviezo T, Zhao Z (2016a) The harlequin ladybird, Harmonia axyridis: global perspectives on invasion history and ecology. Biol Invasions 18(4):997-1044. https://doi.org/10.1007/s10530016-1077-6

Roy HE, Hesketh H, Purse BV, Eilenberg J, Santini A, Scalera R, Stentiford GD, Adriaens T, Bacela-Spychalska K, Bass D, Beckmann KM, Bessell P, Bojko J, Booy O, Cardoso AC, Essl F, Groom Q, Harrower C, Kleespies R, Martinou AF, van Oers MM, Peeler EJ, Pergl J, Rabitsch W, Roques A, Schaffner F, Schindler S, Schmidt BR, Schönrogge K, 
Smith J, Solarz W, Stewart A, Stroo A, Tricarico E, Turvey KMA, Vannini A, Vilá M, Woodward S, Wynns AA, Dunn AM (2016b) Alien pathogens on the horizon: opportunities for predicting their threat to wildlife. Conserv Lett 10(4):477-484. https://doi.org/10.1111/conl.12297

RStudio (2016) RStudio: integrates development environment for R. https://www.rstudio.com/. Accessed 12 Jan 2016

Sabelis MW (1992) Arthropod predators. In: Crawley MJ (ed) Natural enemies: the population biology of predators, parasites and diseases. Blackwell Publishing Ltd, Oxford, pp 225-264

Salo P, Korpimäki E, Banks PB, Nordström M, Dickman CR (2007) Alien predators are more dangerous than native predators to prey populations. Proc Soc 274(1615):1237-1243. https://doi.org/10.1098/rspb.2006. 0444

Seebens H, Blackburn TM, Dyer E, Genovesi P, Hulme PE, Jeschke JM, Pagad S, Pyšek P, Winter M, Arianoutsou M, Bacher S, Blasius B, Brundu G, Capinha C, Celesti-Grapow L, Dawson W, Dullinger S, Fuentes N, Jäger H, Kartesz J, Kenis M, Kreft H, Kühn I, Lenzner B, Liebhold A, Mosena A, Moser D, Nishino M, Pearman D, Pergl J, Rabitsch W, Rojas-Sandoval J, Roques A, Rorke S, Rossinelli S, Roy HE, Scalera R, Schindler S, Štajerová K, Tokarska-Guzik B, van Kleunen M, Walker K, Weigelt P, Yamanaka T, Essl F (2017) No saturation in the accumulation of alien species worldwide. Nat Commun 15(8):14435. https://doi.org/10.1038/ncomms14435

Shapiro-Ilan DI, Cottrell TE (2011) Susceptibility of lady beetles (Coleoptera: Coccinellidae) to entomopathogenic nematodes. J Invertebr Pathol 89(2005):150-156. https:// doi.org/10.1016/j.jip.2005.04.002

Strauss A, White A, Boots M (2012) Invading with biological weapons: the importance of disease-mediated invasions. Funct Ecol 26(6):1249-1261. https://doi.org/10.1111/ 1365-2435.12011

Strayer DL (2010) Alien species in fresh waters: ecological effects, interactions with other stressors, and prospects for the future. Freshw Biol 55(Suppl. 1):152-174. https://doi. org/10.1111/j.1365-2427.2009.02380.x

Toscano BJ, Newsome B, Griffen BD (2014) Parasite modification of predator functional response. Oecologia 175(1):345-352. https://doi.org/10.1007/s00442-0142905-y

Uiterwaal SF, Delong JP (2018) Multiple factors, including arena size, shape the functional responses of ladybird beetles. J Appl Ecol 55:2429-2438. https://doi.org/10. 1111/1365-2664.13159

Van Leeuwen E, Brannstrom A, Jansen VAA, Dieckmann U, Rossberg AG (2013) A generalized functional response for predators that switch between multiple prey species. J Theor Biol 328:89-98. https://doi.org/10.1016/j.jtbi. 2013.02.003

Verheggen FJ, Vogel H, Vilcinskas A (2017) Behavioral and immunological features promoting the invasive performance of the harlequin ladybird Harmonia axyridis. Front Ecol Evol 5(December):1-11. https://doi.org/10.3389/ fevo.2017.00156

Vey A, Jacques F (1977) Histological and ultrastructural studies of Beauveria bassiana infection in Leptinotarsa decemlineata larvae during ecdysis. J Invertebr Pathol 30(2):207-215

Vilcinskas A (2015) Pathogens as biological weapons of invasive species. PLoS Pathog 11(4):e1004714. https://doi.org/ 10.1371/journal.ppat.1004714

Vilcinskas A, Stoecker K, Schmidtberg H, Röhrich CR, Vogel H, Rohrich CR, Vogel H (2013) Invasive harlequin ladybird carries biological weapons against native competitors. Science (80-) 340:862-863. https://doi.org/10.1126/ science. 1234032

Ware RL, Majerus MEN (2008) Intraguild predation of immature stages of British and Japanese coccinellids by the invasive ladybird Harmonia axyridis. BioControl 53:169-188. https://doi.org/10.1007/s10526-007-9135-8

Woodward G, Warren P (2007) Body size and predatory interactions in freshwaters: scaling from individuals to communities. In: Hildrew AG, Rafaelli D, Edmonds-Brown VR (eds) Body size: the structure and function of aquatic ecosystems. Cambridge University Press, Cambridge, pp 98-117. https://doi.org/10.1017/CBO9780511611223. 007

Wright HA, Wootton RJ, Barber I (2006) The effect of Schistocephalus solidus infection on meal size of three-spined stickleback. J Fish Biol 68(3):801-809. https://doi.org/10. 1111/j.0022-1112.2006.00966.x

Wu P, Zhang J, Haseeb M, Yan S, Kanga L, Zhang R (2018) Functional responses and intraspecific competition in the ladybird Harmonia axyridis (Coleoptera: Coccinellidae) provided with Melanaphis sacchari (Homoptera: Aphididae) as prey. Eur J Entomol 115:232-241. https://doi.org/ 10.14411/eje.2018.022

Xue Y, Bahlai CA, Frewin A, Sears MK, Schaafsma AW (2009) Predation by Coccinella septempunctata and Harmonia axyridis (Coleoptera: Coccinellidae) on Aphis glycines (Homoptera: Aphididae). Environ Entomol 38(3):708-714

Publisher's Note Springer Nature remains neutral with regard to jurisdictional claims in published maps and institutional affiliations. 